\title{
DEGRADACE TAHOVÉ ÚNOSNOSTI TVAROVANÉ KOMPOZITNÍ VÝZTUŽE VLIVEM ALKALICKÉHO PROSTŘEDÍ
}

\author{
DEGRADATION OF TENSILE LOAD-BEARING CAPACITY OF MOLDED \\ COMPOSITE REINFORCEMENT DUE TO ALKALINE ENVIRONMENT
}

Juraj Lagiň ${ }^{*}, 1$

*lagin.j@ffce.vutbr.cz

${ }^{1}$ Vysoké učení technické v Brně, Fakulta stavební, Ústav betonových a zděných konstrukcí

\begin{abstract}
Abstrakt
Hlavním důvodem nahrazení běžné využívané betonářské výztuže kompozitní výztuží, je u přímých prvků její vysoká odolnost vǔči agresivnímu prostředí. U př́mé výztuže je tato problematika rozsáhle popsána a prozkoumána. U tvarované, resp. ohýbané výztuže nastávají při výrobě během ohýbacího procesu strukturální změny průřezu, které mohou zásadním způsobem ovlivnit její únosnost $\mathrm{v}$ tahu. Výzkumná činnost popsána v článku byla zaměřena na zjištění změn tahové únosnosti ohýbané kompozitní výztuže pozůstávajících ze sklených vláken a epoxidové matrice. Výztuž byla umístěna do tří druhů lázní, úlohou kterých bylo simulovat různé prostředí, resp. stáří výztuže.

Článek popisuje porovnání př́mé a ohýbané výztuže, způsoby porušení výztuže a porovnání s výpočetním vztahem. Výsledky výzkumu potvrzují vysokou odolnost (prímé) výztuže vůči agresivnímu prostředí. U tvarované (ohýbané) výztuže byla pozorována redukce tahové únosnosti. Míra redukce u nejvíce exponovaného vzorku přesáhla až 33\%, co naznačuje, že výpočetní vztah dle japonské JSCE nelze použít pro výpočet tahové únosnosti kompozitní výztuže vystavené agresivnímu alkalickému prostředí.
\end{abstract}

\section{Klíčová slova}

Ohýbaná kompozitní výztuž, sklená kompozitní výztuž (GFRP), degradace kompozitní výztuže

\begin{abstract}
The main reason for replacing the commonly used concrete reinforcement with composite reinforcement is its high resistance to aggressive environments. For direct reinforcement, this issue has been well described and investigated. In the case of shaped (bent) reinforcement, structural changes in the cross-section occur during the bending process, which can significantly affect its tensile capacity. The research work described in this paper was aimed at investigating changes in the tensile load-bearing capacity of bent glass fibre and epoxy matrix composite reinforcement. The reinforcement was placed in three types of baths, which simulates different environments or reinforcement ages.

The paper describes the comparison of straight and bent reinforcement, comparison of calculation relationship, methods of reinforcement failure and variables affecting the resulting tensile load-bearing capacity of reinforcement. The research results confirm the high resistance of (straight) reinforcement to aggressive environments. A reduction in tensile strength was observed for the shaped (bent) reinforcement. The reduction rate for the most exposed specimen exceeded up to $33 \%$, indicating that the calculation relationship according to the Japanese JSCE cannot be used to calculate the tensile load-bearing capacity of composite reinforcement exposed in aggressive alkaline environments.
\end{abstract}

\section{Key words}

Bended composite reinforcement, glass composite reinforcement (GFRP), degradation of composite reinforcement 


\section{1 ÚVOD}

Př́ímá kompozitní výztuž je z hlediska základních mechanických vlastností dnes již široce prozkoumána, její návrh $\mathrm{v}$ běžných návrhových situacích se stává rutinním. Odlišná situace nastává v př́ípadě návrhu tvarově zakřivených prutů, nebot’ s ohledem na složení a výrobu FRP výztuží se jedná o ortotropní materiál, který při namáhání jinými než tahovým silami ve směru nosných vláken vykazuje násobně nižší hodnoty únosnosti. V závislosti na úhlu odklonu působící síly od podélné osy výztuže tahová únosnost výztuže klesá - viz např. [1]. K zásadní redukci tahové únosnosti dochází při realizaci zakřivení výztuže, kdy redukce únosnosti může v závislosti na poloměru v místě ohybu dosahovat až $50 \%$ [2].

Zásadní výhodou kompozitní výztuže je její vysoká odolnost vůči agresivním prostředím [3]. Četné studie však prokázaly, že alkalické prostř̌edí může, v závislosti na typu využitých vláken, způsobovat její degradaci [4]. Tyto studie však byly realizovány výhradně na přimých výztužích. Tvarově zakřivená (ohýbaná) výztuž, u které dochází během procesu výroby $\mathrm{k}$ změnám rozložení vláken a matrice po prưřezu a častěji $\mathrm{k}$ výrobním nehomogenitám, může vykazovat vyšších hodnot redukce tahové únosnosti v čase. V následujícím textu je z tohoto důvodu stručně sumarizován vliv agresivního alkalického prostředí na FRP výztuž a uvedeny dílčí výsledky experimentu realizovaného na VUT v Brně s cílem stanovit tahovou únosnost zakřivené výztuže při souběžném působení zvýšené teploty a alkálií.

\section{TEORETICKÉ PŘEDPOKLADY}

Kompozitní výztuž se skládá z nosných vláken, které zabezpečují přenos tahových sil a matrice zajištující prríčnou tuhost, spolupůsobení vláken a ochranu vláken vůči okolnímu prostředí. V prrípadě termosetický matric, které jsou při výrobě FRP výztuží nejčastěji využívány, je nutno tvar výztuže upravovat již před procesem finálního vytvrzení. Při výrobě je výztuž po průchodu vláken matricí tvarována a pouze částečně vytvrzena. Následně dochází $\mathrm{k}$ ohýbání do požadovaného tvaru a poté $\mathrm{k}$ vytvrzení do finální podoby. Během procesu výroby tak dochází ke změnám ve struktuře prưřezu. Vlivem tlaku ohýbacího mechanismu je matrice vytlačována z průřezu, vlákna mění svou délku a ztrácí rovinnost (a zároveň účinnost). Také často dochází k částečnému sejmutí povrchové vrstvy výztuže.

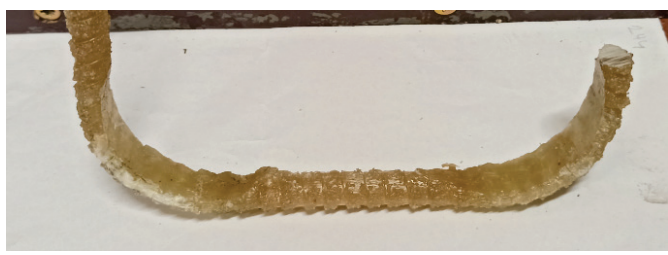

Obr. 1 Zakřivená kompozitní výztuž; vzorek L_GFRP.

\section{Stanovení míry redukce tahové únosnosti zakřivené výztuže}

Redukci tahové únosnosti lze stanovit na základě vztahu uvedeného v japonské JSCE [5]:

$$
f_{f b}=\left(0,05 \frac{R}{d_{b}}+0,3\right) f_{f u} \leq f_{f u}
$$

kde $\mathrm{R}$ značí poloměr zakřivení, $\mathrm{d}_{\mathrm{b}}$ průměr prutu a $\mathrm{f}_{\mathrm{fu}}$ mezní tahová únosnost př́mé části prutu. Konstanta 0,05 představuje pravděpodobnost odchylky. Tuto hodnotu je možno navýšit až na 0,092 , což však sebou nese vysoké riziko nadhodnocení skutečného chování. Pro výsledný vztah byla proto konzervativně zvolena hodnota 0,05 [5].

\section{Vliv alkalického prostředí}

Kompozitní FRP výztuž je $\mathrm{v}$ betonových prvcích nejčastěji vystavena vlhkosti a zásaditému $\mathrm{pH}$ až o hodnotě 12,5-14,0. Na působení alkálií jsou citlivá především skleněná vlákna a v důsledku tedy i kompozitní výztuž na bázi těchto vláken (GFRP). Princip degradace je podobný pro alkalické, kyselinové, nebo jiné prostředí na bázi tekutin. Částice difundují do matrice výztuže, což způsobí její nabývání (bobtnání) a poškození rozhraní matrice a vláken. Tento proces vede ke vzniku mikrotrhlin, degradaci tuhosti materiálu a redukci mechanických vlastností výztuže. 
Vliv degradace není pro všechny typy materiálů stejná. Např. z výsledků studie [6] a [7] je zřejmé, že vliv degradace je nejvyšší pro skelná vlákna a nejnižší pro uhlíková vlákna. Bylo také prokázáno, že zvolením správného materiálu matrice jsou vlákna dostatečně chráněna a $\mathrm{k}$ degradaci výztuže $\mathrm{v}$ zásadní míře nemusí docházet [8], [9]. Studie [8], [9], [10] také prokazují, že použití vinylesterové nebo epoxidové matrice lze pokládat za vhodnější než matrice na bázi polyesteru.

\section{Vliv teploty}

Při provádění degradačních testů je s výhodou využíváno akceleračního faktoru teploty prostředí, ve kterém jsou výztuže uloženy. Dochází k urychlení procesu stárnutí kompozitu [16], [17]. Ve studiích [11] a [12] bylo poukázáno na fakt, že lázeň s teplotou cca $60{ }^{\circ} \mathrm{C}$ může u výztuží s nižší kvalitou vytvrzení matrice způsobovat nejen urychlení samotného testu, ale také nežádoucí degradaci mechanický vlastností, což v důsledku zkresluje dosažené výsledky. Je proto vždy nezbytné uvážit, jaké reálné teplotě bude výztuž v průběhu životnosti vystavena (tj. zdali teplota nedosahuje hodnot blízkých teplotě skelného přechodu matrice Tg. Při této teplotě matrice výztuže začíná významně měnit odezvu na vnášené zatížení, ztrácí tuhost a významně redukuje své mechanické vlastnosti).

\section{KONFIGURACE EXPERIMENTU}

Zahraniční literatura uvádí několik způsobů testování tahové únosnosti nepřímé výztuže. Nejpoužívanějšími jsou metody B.5 a B.12 uvedené v americké směrnici ACI 440.3R-12 [13], které předpokládají testování výztuže v podobě třmínků. Porovnání obou zmíněných metod bylo provedeno ve studii [14]. Bylo zjištěno, že postup B.12 výsledky podhodnocuje. Pro dosažení realistického výsledku je autory studie [14] doporučeno testovanou výztuž umístit do betonu, tj. využít test v konfiguraci B.5.

Vzhledem k možnostem laboratorní techniky byla koncepce metody B.5 upravena [15]. Na základě zjištění z předešlých experimentálních testů byla jako vhodná zvolena konfigurace vzorku s označením „L_GFRP“, která je patrna z Obr. 2 [15].

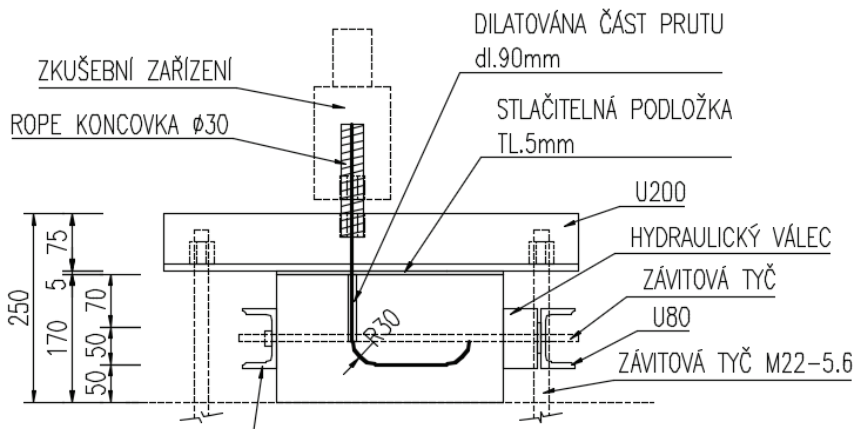

Obr. 2 Konfigurace a osazení vzorku "L_GFRP".

Vzhledem k nutnosti dostatečného kotvení výztuže v koncovkách (min.150 mm) a výrobních omezeních třmínků, kdy svislou větev nebylo možné vyhotovit v delším provedení, byl betonový blok výškově omezen. U vzorků výztuže s vyšší únosnosti bylo pro zabránění nežádoucího porušení betonového bloku vneseno př́icné tlakové napětí 4,60MPa.

Základním cílem experimentu bylo stanovení vlivu degradace zakřivené GFRP výztuže v alkalickém prostředí. Vzorky byly z tohoto důvodu po požadovaný čas exponovány roztoku s cíleným pH. Složení alkalické lázně a konfigurace testu bylo navrženo dle [13]. Roztok ve složení $118,5 \mathrm{~g} \mathrm{Ca}(\mathrm{OH}) 2,0,9 \mathrm{NaOH}$ a $4,2 \mathrm{~g} \mathrm{KOH}$ na 11 deionizované vody s výsledným pH 12,6 až 13,0 dle [13] simuluje prostředí pórů zralého betonu.

Pro zjištění míry redukce tahové únosnosti byly současně s ohýbanou výztuží prováděny také zkoušky přímých prutů. Časové intervaly ponoření vzorku v lázni byly zvoleny na 30, 42 a 90 dnů. Experiment však dále pokračuje, další testovaný čas bude 180 dní. 
Vzorky byly vystaveny prostředí tří typů (A, B a C) - viz Tab. 1 - a po stanovených časech vyjmuty z lázně, důkladně očištěny deionizovanou vodou, osušeny a následně testovány dle zvolené konfigurace testu.

Tab. 1 Značení experimentálních vzorků a testované podmínky prostředí.

\begin{tabular}{|c|c|c|c|c|c|c|}
\hline $\begin{array}{l}\text { Označení } \\
\text { prostředí }\end{array}$ & Typ lázně & Teplota lázně & $\begin{array}{l}\text { Materiál } \\
\text { nosných } \\
\text { vláken }\end{array}$ & $\begin{array}{c}\text { Materiál } \\
\text { matrice }\end{array}$ & $\begin{array}{c}\text { Deklarovaný } \\
\text { průměr } \\
\text { [mm] }\end{array}$ & $\begin{array}{c}\text { Poloměr } \\
\text { zakřivení } \\
\text { [mm] }\end{array}$ \\
\hline $\mathbf{A}$ & $\mathrm{H} 2 \mathrm{O}$ & \multirow{2}{*}{$20^{\circ} \mathrm{C}$} & \multirow{3}{*}{ E-sklo } & \multirow{3}{*}{ Epoxid } & \multirow{3}{*}{10} & \multirow{3}{*}{30} \\
\hline B & \multirow{2}{*}{ Alkálie } & & & & & \\
\hline C & & $40^{\circ} \mathrm{C}$ & & & & \\
\hline
\end{tabular}

Zavedené znační vzorků: „L_GFRP_počet dnů lázně_prostředí“. Celkem bylo odzkoušeno 48 vzorků ohýbané výztuže a 42 kusů př́mé výztuže. V každé variantě lázně a času bylo testováno 5 ks vzorků ohýbané výztuže a 4ks přímé výztuže. Jako referenční - neexponované - byly testovány $3 \mathrm{ks}$ v konfiguraci „L_GFRP“ a $6 \mathrm{ks}$,GFRP“.

\section{VÝSLEDKY}

Z Obr. 3 až Obr. 5 jsou zřejmé detaily v místě zakřivení testované výztuže po expozici v čase 90 dnů. U Obr. 4 a Obr. 5 je jasně patrná vysrážená vrstva vápenatých solí, kdy její mocnost je přímo úměrná času expozice a teplotě lázně. U vzorku L_FRP - A (Obr. 3) došlo jen k mírnému zesklovatění povrchu.

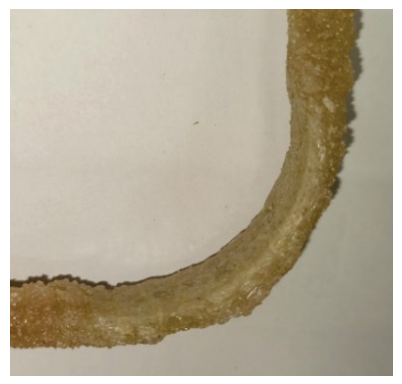

Obr. 3 L_FRP_90d - A.

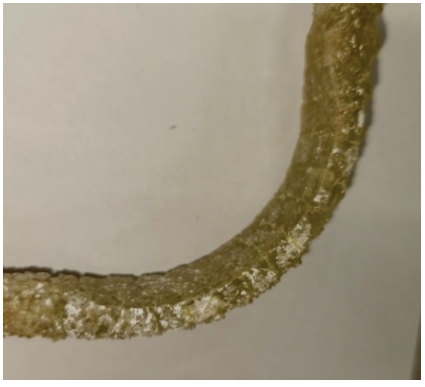

Obr. 4 L_FRP_90d - B.

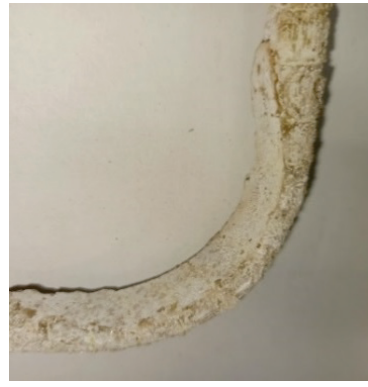

Obr. 5 L_FRP_90d - C.

Mechanické charakteristiky získané z výše uvedených zkoušek jsou sumarizovány v Tab. 2 . Uvedené výsledky jsou vztaženy ke vzorku s plným, nezploštěným, průřezem s deklarovaným průměrem 10mm.

Tab. 1 Značení experimentálních vzorků a testované podmínky prostředí.

\begin{tabular}{|c|c|c|c|c|c|c|}
\hline \multirow[t]{2}{*}{ Typ } & \multirow[t]{2}{*}{ Označení } & \multirow{2}{*}{$\begin{array}{c}\text { Deklar. } \\
\text { průměr } \\
{[\mathrm{mm}]}\end{array}$} & \multicolumn{4}{|c|}{$\begin{array}{l}\text { Stř̌ední tahová únosnost } \pm \text { směrodatná odchylka } \\
{[\mathrm{MPa}]}\end{array}$} \\
\hline & & & 0 dnů (ref.) & 30 dnů & 42 dnů & 90 dnů \\
\hline \multirow{3}{*}{ 裻 } & $G F R P_{-} A$ & \multirow{6}{*}{10} & \multirow{3}{*}{$1367,74 \pm 24,86$} & $1302,30 \pm 14,19$ & $1267,38 \pm 28,17$ & $1283,78 \pm 43,64$ \\
\hline & $G F R P_{-} B$ & & & $1296,70 \pm 25,22$ & $1285,65 \pm 20,85$ & $1275,28 \pm 23,87$ \\
\hline & $G F R P_{-} C$ & & & $1278,68 \pm 25,62$ & $1242,62 \pm 36,78$ & $1277,63 \pm 30,76$ \\
\hline \multirow{3}{*}{ 齐 } & $L_{-} G F R P_{-} A$ & & \multirow{3}{*}{$704,87 \pm 46,64 *$} & $826,21 \pm 77,25^{*}$ & $754,74 \pm 50,58$ & $703,37 \pm 23,02$ \\
\hline & $L_{-} G F R P_{-} B$ & & & $760,76 \pm 49,76$ & $696,76 \pm 29,92$ & $681,35 \pm 64,63$ \\
\hline & $L_{-} G F R P \_C$ & & & $749,14 \pm 22,58$ & $671,29 \pm 43,63$ & $549,12 \pm 44,29$ \\
\hline
\end{tabular}


Grafické znázornění výsledků tahové únosnosti přimých výztuží („GFRP“) a zakřivených výztuží („L_GFRP“) v závislosti na době expozice je vyobrazeno na Obr. 6. Z důvodu odlišných okrajových podmínek (zavedené tlakové napětí do vzorků v čase 30 dní a dále) nejsou vzorky L GFRP Od do vyhodnocení uvažovány. Značení „JSCE“ reprezentuje krátkodobou tahovou únosnost ohybu určenou dle vztahu (1) při uvážení aktuální únosnosti př́mého prutu, tj. tahové únosnosti odpovídající danému typu lázně a doby expozice.

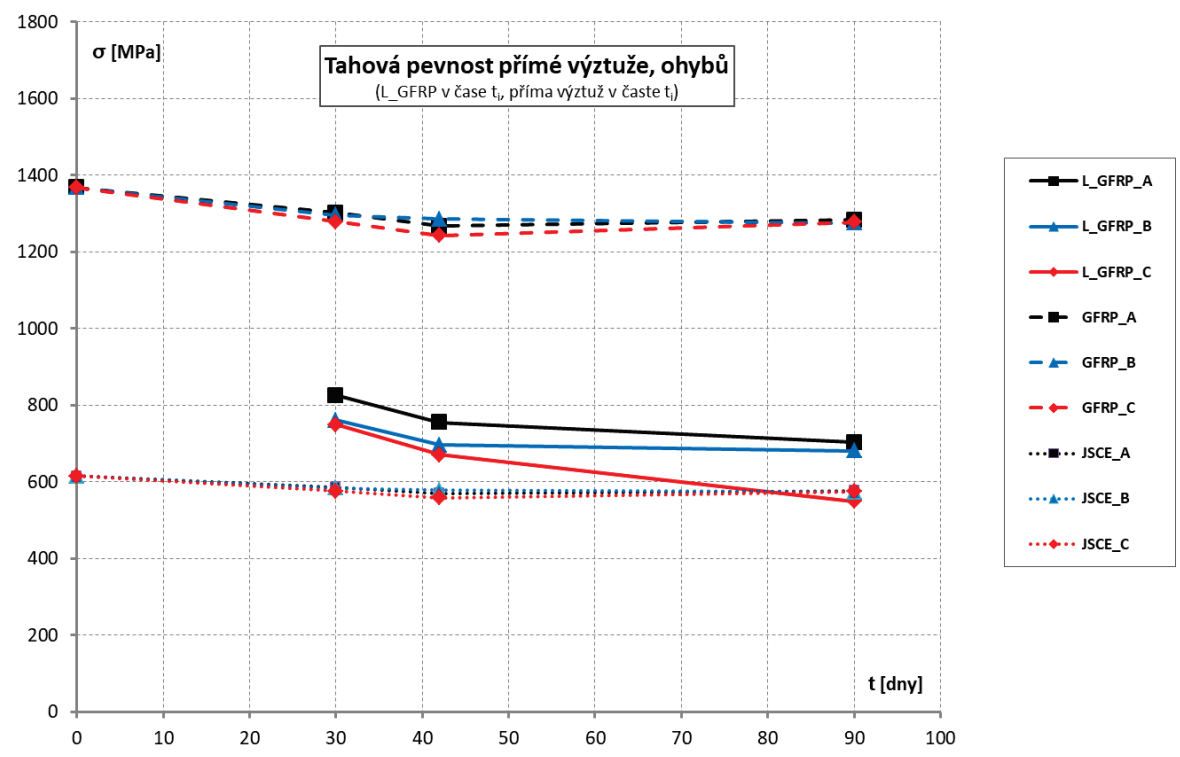

Obr. 6 Tahová únosnost vzorků v závislosti na době expozice - př́ímé výztuže, ohýbané výztuže.

Typické porušení výztuže v čase 90 dnů je vyobrazeno na Obr. 7 až Obr. 9 . K porušení obecně docházelo z důvodu koncentrace napětí a přetržení nosných vláken na počátku ohybu. Prvky byly po porušení podrobeny vizuálnímu zkoumání. Nevykazovaly zásadní změny ve struktuře materiálu. Pro přesnější stanovení je plánováno další zkoumání na mikroskopické úrovni.

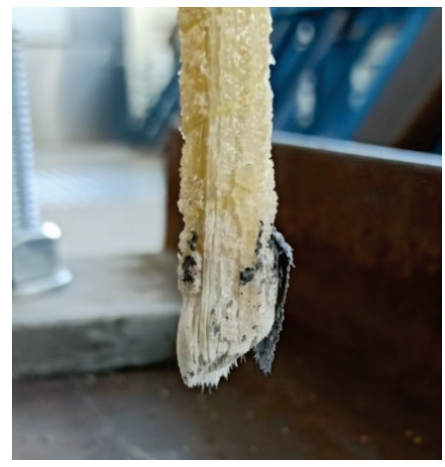

Obr. 7 L_GFRP_90d_A.

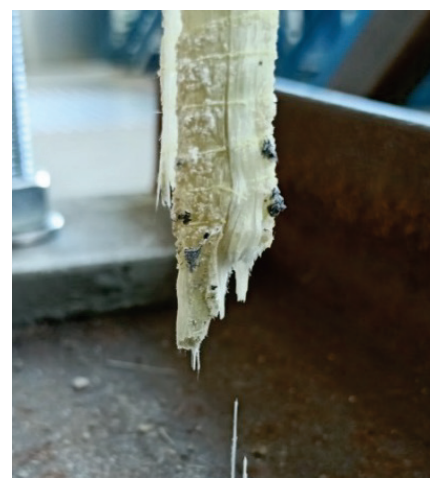

Obr. 8 L_GFRP_90d_B.

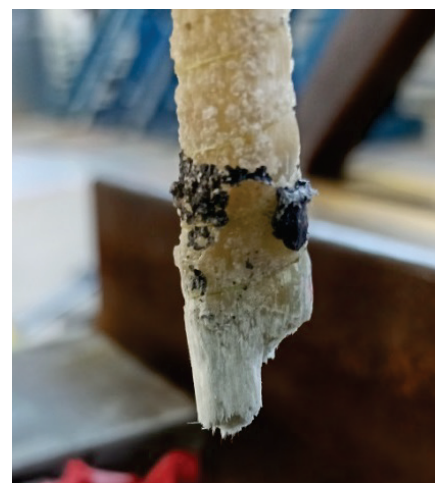

Obr. 9 L_GFRP_90d_C. 


\section{ZÁVĚR}

V rámci provedené experimentální studie bylo doposud ověřeno chování vzorkủ zakřivených GFRP výztuží vystavených agresivnímu prostředí po dobu 90 dní. Testy budou i nadále pokračovat v delších expozičních časech. I přses poměrně krátkou dobu expozice lze vyslovit následující závěry:

- př́mé výztuže ve sledovaném intervalu vykazují mírný pokles tahové únosnosti (z 1367,74 $\pm 24,86$ MPa na $1277,63 \pm 30,76 \mathrm{MPa}$, tedy přibližně o $6,3 \%$ ). Vzhledem k nízkému počtu testovaných vzorků (4ks pro jeden typ) a zjištěným hodnotám rozdílu je však tento závěr třeba chápat pouze jako informativní;

- únosnost ohýbané výztuže v krátkém časovém horizontu (0 až 30 dnů) mírně narůstala. Tento jev může být přisouzen především vnesení tlakového napětí do betonu, které bylo aplikováno až v čase 30 a více dnů [15];

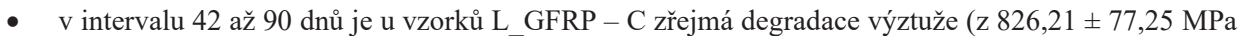
na $549,12 \pm 44,29 \mathrm{MPa}$ - pokles o $3 \overline{3}, 54 \%$ ). Poměr únosnosti ohýbané a přímé výztuže $\mathrm{v}$ daném časovém intervalu poklesl z $63,44 \%$ na $42,98 \%$. V případě porovnání referenční únosnosti př́mé výztuže ( $\mathrm{v}$ čase 0 dnů) a únosností ohybu v čase 90 dnů, byla tahová únosnost zredukována až na 40,15\% původní únosnosti. Z naměřených hodnot experimentů lze tvrdit, že na testovaných vzorcích byla prokázána zvýšená citlivost vzorků na působení alkálii/teploty;

- pro stanovení teoretické predikce únosnosti zakřivené výztuže byla ve vztahu (1) uvážena aktuální tahová únosnost odpovídající danému času a typu lázně. Pro většinu testovaných konfigurací byly predikované hodnoty konzervativní. V čase 90 dnů, kdy byla zjištěná nejvyšší redukce tahové únosnosti ohýbané výztuže, však již byla hodnota očekávaná dle vztahu (1) mírně vyšší (o 4,49\%). Tato skutečnost naznačuje, že vztah (1) nemusí plně vystihovat dlouhodobé chování/redukci únosnosti zakřivených výztuží. Pro potvrzení tohoto konstatování je však nutno experiment dále doplnit o další vzorky a časové intervaly;

- pozorovaný způsob porušení byl pro všechny vzorky totožný. K porušení docházelo z důvodu koncentrace napětí na začátku ohybu. Snížení redukce únosnosti lze dosáhnout zabezpečením efektivnějšího roznosu napětí podél ohybu [15]. Toto tvrzení bylo nepřímo prokázáno navýšením únosnosti vzorků při vnesení tlakové síly do betonu;

- naměřené hodnoty vykazovaly vysokou míru rozptylu. Pro potvrzení vyslovených závěrů je nutno realizovat vyšší počet vzorků a experiment doplnit o delší časové intervaly.

\section{Poděkování}

Autoři děkují výzkumnému centru AdMaS a společnosti PREFA KOMPOZITY, a.s. za poskytnutí vzorků a realizaci experimentů. Výzkum bylo možné realizovat z prostředku juniorského projektu FAST-J-21-7490 Vliv alkalického prostředí na mechanické vlastnosti ohýbané kompozitní výztuže, standartního projektu FASTS-21-7503 - Využití nepř́mých FRP výztuží při návrhu vybraného detailu bodově podepřené stropní konstrukce a projektu FW01010520 - Vývoj ohýbané kompozitní výztuže pro environmentálně exponované betonové konstrukce.

\section{Použité zdroje}

[1] GIRGLE, František, Vojtech KOSTIHA, Ondřej JANUŠ, Pavel ŠULÁK, Petr ŠTĚPÁNEK a Ivana ŠVAŘIČCKOVÁ. Experimentání stanovení únosnosti GFRP výztuže při souběžném namáhání tahovou a smykovou silou. Zborník príspevkov z 11. seminára SANÁCIA BETÓNOVÝCH KONŠTRUKCIÍ. Bratislava: Združenie pre sanáciu betónových konštrukcií pri SZSI, Bratislava, 2019, s. 89-94. ISBN 978-80-227-4973-2.

[2] FIB Bulletin no.40: FRP reinforcement in RC structures. . Germany: The International Federation for Structural Concrete; 2007

[3] CERONI, Francesca, Edoardo COSENZA, Manfredi GAETANO a Marisa PECCE. Durability issues of FRP rebars in reinforced concrete members. Cement and Concrete Composites [online]. 2006, 28(10), 857-868 [cit. 2021-7-26]. ISSN 09589465. Dostupné z: doi:10.1016/j.cemconcomp.2006.07.004

[4] TIANQIAO, Liu, Liu XING a Feng PENG. A comprehensive review on mechanical properties of pultruded FRP composites subjected to long-term environmental effects. Composites Part B. Elsevier, 2020, .(.), 57. Dostupné z: doi:doi.org/10.1016/j.compositesb.2020.107958 
[5] JSCE: Recommendation for Design and Construction ofConcrete Structures using Continuous Fiber Reinforcing Materials. 1997 ed. Japan: Research Committee on Continuous Fiber Reinforcing Materials, Japan Society of Civil Engineers; 1997.

[6] MACHIDA, A. State-of-the-art report on continuous fiber reinforcing materials. Second Research Committee on CFRM, Japan Society of Civil Engineers: Concrete Engineering Series, 1993, 3.

[7] LU, Chunhua, Mingzhi NI, Tianshu CHU a Liyuan HE. Comparative Investigation on Tensile Performance of FRP Bars after Exposure to Water, Seawater, and Alkaline Solutions. Journal of Materials in Civil Engineering. 2020, 32(7), 1-12. ISSN 0899-1561. Dostupné z: doi:10.1061/(ASCE)MT.1943-5533.0003243

[8] KOOTSOOKOS, A. a A.P. MOURITZ. Seawater durability of glass- and carbon-polymer composites. Composites Science and Technology. 2004, 64(10-11), 1503-1511. ISSN 02663538. Dostupné z: doi:10.1016/j.compscitech.2003.10.019

[9] VISCO, A.M., N. CAMPO a P. CIANCIAFARA. Comparison of seawater absorption properties of thermoset resins based composites. Composites Part A: Applied Science and Manufacturing. 2011, 42(2), 123-130. ISSN 1359835X. Dostupné z: doi:10.1016/j.compositesa.2010.10.009

[10] MICELLI, Francesco a Antonio NANNI. Durability of FRP rods for concrete structures. Construction and Building Materials. Elsevier, 2004, .(18), 13. Dostupné z: doi:10.1016/j.conbuildmat.2004.04.012

[11] STEPANEK, Petr, Ondrej JANUS, Frantisek GIRGLE, Lenka BODNAROVA, Vojtech KOSTIHA a Iva ROZSYPALOVA. Long term strength of internal GFRP reinforcement by alkaline, temperature and cyclic loading. Procedia Structural Integrity [online]. 2018, 11(1), 12-19 [cit. 2021-7-29]. ISSN 24523216. Dostupné z: doi:10.1016/j.prostr.2018.11.003

[12] GIRGLE, František, Lenka BODNÁROVÁ, Ondřej JANUŠ a Vojtěch KOSTIHA. Influence of Alkalinity and Ambient Temperature on Long-Term Properties of GFRP Reinforcement. Key Engineering Materials. 2018, 760(1), 213-218. ISSN 1662-9795. Dostupné z: doi:10.4028/www.scientific.net/KEM.760.213

[13] ACI 440.3R-12: Guide Test Methods for Fiber-Reinforced Polymers (FRPs) for Reinforcing or Strengthening Concrete Structures. . Farmington Hills: American Concrete Institute; 2012.

[14] Ahmed EA, El-Sayed AK, El-Salakawy E, Benmokrane B. Bend Strength of FRP Stirrups: Comparison and Evaluation of Testing Methods. Web of Science. 2015;9.

[15] LAGIŇ, Juraj. Tahová pevnost kompozitní výztuže v místě ohybu. VYSOKÉ UČENÍ TECHNICKÉ V BRNĚ, FAKULTA STAVEBNÍ. Sborník přispěvků - Juniorstav 2021. 23. Brno: ECON publishing, s.r.o, 2021, s. 225-230. ISBN 978-80-86433-75-2.

[16] Chen, Y., Davalos, J. F.; Ray, I.; Kim, H.: Accelerated aging tests for evaluations of durability performance of FRP reinforcing bars for concrete structures, Composite Structures, 78. 101-111, 10.1016/j.compstruct.2005.08.015., 2005

[17] Robert, M.; Wang, P.; Cousin, P.; Benmokrane, B.: Temperature as an accelerating factor for long-term durability testing of FRPs: Should there be any limitations?, J. Compos. Constr., 14 (4) (2010), pp. 361-367 